\title{
Potentiation of
}

pancuronium and

vecuronium neuro-

muscular blockade by

intravenous salbutamol

Y. Salib MB ChB FFARCSI, F. Donati PhD MD FRCPC

Three doses of salbutamol $125 \mu \mathrm{g}$ iv were given, over $3.5 \mathrm{hr}$, to a 28-yr-old healthy, previously non-asthmatic man during thiopentone- $\mathrm{O}_{2} / \mathrm{N}_{2} \mathrm{O}$-isoflurane anaesthesia for treatment and prophylaxis of bronchospasm. Force of contraction of the adductor pollicis was measured before and afier the last two injections. Initially, the patient was given pancuronium, $5 \mathrm{mg}$. Salbutamol, $125 \mu \mathrm{g} i$, was given when $T_{l}$ blockade was $45 \%$. Blockade increased to $66 \%$ over five minutes and returned to $45 \%$ afier $18 \mathrm{~min}$. Vecuronium was subsequently used to maintain relaxation. At the end of surgery, salbutamol was followed by an increase in $T_{1}$ blockade, from $66 \%$ to $86 \%$, over five minutes which returned to $66 \%$ after ten minutes. It is concluded that intravenous salbutamol potentiates the neuromuscular blocking effect of nondepolarizing muscle relaxants.

Trois doses de salbutamol $125 \mu \mathrm{g}$ iv sont administrées dans un intervalle de 3 h30 à un patient de 28 ans jusque là en bonne santé pour traitement et prophylaxie d'un bronchospasme, au cours d'une anesthésie au thiopental, $\mathrm{O}_{2} / \mathrm{N}_{2} \mathrm{O}$ et isoflurane. Le patient n'a pas d'antécédents d'asthme. La force de concentration de l'adducteur du pouce est mesurée avant et après les deux dernières injections. Initialement, le patient avait reçu $5 \mathrm{mg}$ de pancuronium. Du salbutamol à la dose de 125

\section{Key words}

COMPLICATIONS: bronchospasm;

INTERACTIONS (DRUG): neuromuscular relaxants;

MONITORING: neuromuscular function;

NEUROMUSCULAR RELAXANTS: pancuronium, vecuronium;

PHARMACOLOGY: salbutamol.

From the Department of Anaesthesia, Royal Victoria Hospital and McGill University, Montreal, Quebec, Canada.

Address correspondence to: Dr. F. Donati, Department of Anaesthesia, Royal Victoria Hospital, 687 Pine Avenue West, Suite S5.05, Montreal, Quebec, Canada H3A 1A1.

Accepted for publication 1st September, 1992. $\mu \mathrm{g}$ iv est donné quand le bloc $T_{1}$ est de $45 \%$. Le bloc augmente jusqu'à $66 \%$ en cinq minutes et revient à $45 \%$ après $18 \mathrm{~min}$. $\mathrm{Du}$ vécuronium est ensuite utilisé pour maintenir la relaxation. $A$ la fin de la chirurgie, le salbutamol a entraîné une augmentation, en cinq minutes, du bloc $T_{1}$ de $66 \%$ à $86 \%$, lequel est revenu à $66 \%$ après dix minutes. On en conclut que le salbutamol iv renforce l'effet bloqueur neuromusculaire des myorelaxants non dépolarisants.

Nondepolarizing muscle relaxants may be potentiated by several drugs, including inhalational agents, ${ }^{1,2}$ local anaesthetics, ${ }^{3}$ antibiotics ${ }^{4,5}$ and calcium-channel blockers. ${ }^{6}$ We would like to report potentiation of pancuroniumand vecuronium-induced neuromuscular blockade by the intravenous administration of salbutamol, a $\boldsymbol{\beta}_{2}$-agonist.

\section{Case report}

A 28-yr-old man, ASA physical status I with no history of asthma, weighing $75 \mathrm{~kg}$, was scheduled for elective repair of an incisional hernia. Two years previously, he was involved in a motor vehicle accident which resulted in pelvic fractures and major abdominal trauma. Multiple intra-abdominal operations had left a large incisional hernia, extending from the xyphoid process to the symphysis pubis. He had smoked ten cigarettes a day for the last five years. The preoperative chest examination was unremarkable. He reported no known allergies and was taking no medications.

In the operating room, ECG, oxygen saturation and arterial blood pressure were monitored non-invasively. Before induction of anaesthesia, the patient was given d-tubocurarine $3 \mathrm{mg}$ and fentanyl $150 \mu \mathrm{g} i \mathrm{v}$. This was followed three minutes later by thiopentone, $500 \mathrm{mg} i v$. Tracheal intubation was facilitated by succinylcholine 200 mg. End-tidal $\mathrm{CO}_{2}, \mathrm{O}_{2}$ and isoflurane concentrations were monitored with a Datex Capnomac gas analyzer (Datex Instrumentarium Corp., Helzinki, Finland). The airway pressure at the mouth end of the endotracheal tube was monitored and displayed as a curve. In addition, 
a digital readout of peak and mean airway pressures was available.

Immediately following intubation, manual ventilation with the reservoir bag was difficult. Mechanical ventilation was instituted and the tidal volume was set at 600 $\mathrm{ml}$. Peak inspiratory pressures (PIP) were high $(28 \mathrm{~cm}$ $\mathrm{H}_{2} \mathrm{O}$ ) and much greater than the plateau pressure (20 $\mathrm{cm} \mathrm{H}_{2} \mathrm{O}$ ). Direct laryngoscopy was performed to verify the position of the tube and confirm the absence of mechanical obstruction. This manoeuvre was followed by a further increase in PIP to $40 \mathrm{~cm} \mathrm{H}_{2} \mathrm{O}$. Bronchospasm was confirmed by auscultation of the chest. This episode was resolved within five minutes as anaesthesia was deepened by increasing the end-tidal isoflurane concentration. The PIP stabilized at $19 \mathrm{~cm} \mathrm{H}_{2} \mathrm{O}$.

After recovery from succinylcholine, muscle relaxation was maintained using pancuronium, $5 \mathrm{mg} i v$. The Paragraph unit (Utah Medical Products) was used for neuromuscular monitoring. This new device contains a nerve stimulator, a movement-sensitive pad for muscle contraction and a screen displaying the train-of-four response as four separate bars. The train-of-four ratio is also computed numerically, but the device does not calculate first twitch height compared with control.

Twenty minutes after induction of anaesthesia and immediately after skin incision, the patient developed another episode of bronchospasm diagnosed by an increase in PIP from 19 to $40 \mathrm{~cm} \mathrm{H}_{2} \mathrm{O}$. Salbutamol, $125 \mu \mathrm{g}$, $i v$ was given and within a few minutes the PIP decreased to $19 \mathrm{~cm} \mathrm{H}_{2} \mathrm{O}$. The inspired isoflurane concentration was not changed.

At the time of salbutamol injection, only the first twitch of the train-of-four $\left(T_{1}\right)$ was visible on the Paragraph screen, and was palpable by tactile evaluation. Two minutes after salbutamol, $T_{1}$ disappeared from the Paragraph screen. Tactile evaluation of the train-of-four confirmed the absence of all four twitches. Ten minutes later, $T_{1}$ started to recover and reached its approximate height before salbutamol injection $20 \mathrm{~min}$ later. Salbutamol injection was also accompanied by a transient increase in heart rate from 80 to $115 \mathrm{~min}^{-1}$ and an increase in blood pressure from $110 / 70$ to $152 / 77 \mathrm{mmHg}$. No arrhythmia other than sinus tachycardia was observed.

To obtain better documentation of the salbutamol effect on neuromuscular blockade, it was then decided to use a Grass FT-10 force-displacement transducer to measure and record the force of contraction of the adductor pollicis. Forty minutes after the first injection, a second dose of $125 \mu \mathrm{g}$ salbutamol was given $i$ to treat another episode of bronchospasm. At injection, $T_{1}$ blockade was $45 \%$ (using the maximum height of $\mathrm{T}_{1}$ after reversal as a control) and train-of-four ratio was $14 \%$. Two minutes later, there was a gradual increase in $T_{1}$ blockade to a

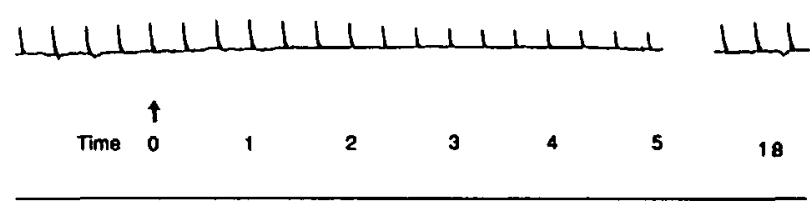

FIGURE 1 Pancuronium-induced neuromuscular blockade. Arrow marks salbutamol injection. Force of contraction of adductor pollicis in response to train-of-four stimulation of the ulnar nerve is displayed versus time. $T_{1}$ blockade increased from $45 \%$ to $66 \%$ over five minutes. This was followed by gradual recovery to its height before salbutamol injection after $18 \mathrm{~min}$. Time scale is in minutes.

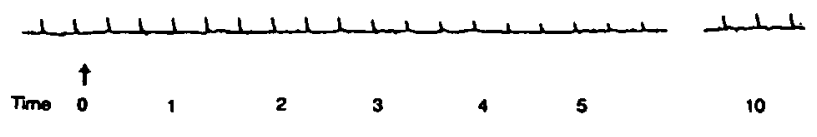

FIGURE 2 Vecuronium-induced neuromuscular blockade. Arrow marks salbutamol injection. Force of contraction of adductor pollicis in response to train-of-four stimulation of the ulnar nerve is displayed versus time. $T_{1}$ blockade increased from $66 \%$ to $86 \%$ over five minutes. This was followed by gradual recovery to its height before salbutamol injection after ten minutes. Time scale is in minutes.

maximum of $66 \%$ after five minutes. The train-of-four ratio decreased to $10 \%$. This was followed by gradual recovery to its pre-salbutamol height after $18 \mathrm{~min}$ (Figure 1). Cardiovascular changes similar to those which followed the first dose were also observed. These were transient and required no treatment.

Because the patient was receiving a drug which potentiated neuromuscular blockade, it was decided to maintain relaxation with a shorter-acting muscle relaxant. Over the next $2.5 \mathrm{hr}$, muscle relaxation was maintained by five incremental doses of vecuronium, $1 \mathrm{mg}$. Eighteen minutes before reversal, and $22 \mathrm{~min}$ after the last dose of vecuronium, salbutamol, $125 \mu \mathrm{g} i v$, was given to prevent any bronchospasm which might accompany emergence from anaesthesia. At injection, $T_{1}$ blockade was $66 \%$ and train-of-four ratio was $12 \%$. Five minutes later, $\mathrm{T}_{1}$ blockade reached a maximum of $86 \%$, and only three twitches were visible. This was followed by gradual recovery to the pre-salbutamol value after ten minutes (Figure 2).

The surgical procedure lasted for $3.5 \mathrm{hr}$. Since the resolution of the first episode of bronchospasm, the endtidal isoflurane concentration had been maintained at $0.6 \%$ with no alteration during salbutamol treatment. Isoflurane administration was discontinued shortly before reversal. The residual blockade was reversed with glycopyrrolate $0.6 \mathrm{mg}$ and neostigmine $2.5 \mathrm{mg}$, when $\mathrm{T}_{1}$ blockade was $55 \%$ and $T_{4} / T_{1}$ was $16 \%$. Both $T_{1}$ and 
$T_{4} / T_{1}$ increased slowly, but ten minutes after reversal, $T_{4} / T_{1}$ was only 0.6 . The patient was observed carefully in the recovery area. He had no more bronchospasm, showed no signs of residual weakness, and the rest of his hospitalization was unremarkable.

\section{Discussion}

This case report demonstrates that severe intraoperative bronchospasm can occur in non-asthmatic patients. Salbutamol $i v$ is an effective treatment. However, it can potentiate the nondepolarizing muscle relaxants and delay recovery after reversal.

The two main lines of treatment of intraoperative bronchospasm are deepening the anaesthetic level (by intravenous or inhalational anaesthetics) and using bronchodilators. ${ }^{7}$ Deepening the anaesthetic level was tried first, but as bronchospasm recurred with skin incision, it was decided to use salbutamol.

Salbutamol is a synthetic sympathomimetic drug with predominant effect on $\beta_{2}$ receptors of the bronchial musculature. It can be administered orally, by inhalation or intravenously, for the symptomatic treatment of bronchospasm. The recommended intravenous dose is $4 \mu \mathrm{g} \cdot \mathrm{kg}^{-1}$ repeated after $15 \mathrm{~min}$ if necessary, to a maximum of $1,000 \mu \mathrm{g}$. Our patient received three bolus doses of 125 $\mu \mathrm{g}$ (less than $2 \mu \mathrm{g} \cdot \mathrm{kg}^{-1}$ ), for a total of $375 \mu \mathrm{g}$. Although salbutamol is as potent as isoproterenol on $\beta_{2}$ receptors, it is considerably less potent on $\beta_{1}$ receptors $^{8}$ and thus cardiovascular effects do not occur unless it is administered intravenously or in large doses (more than 400 $\mu \mathrm{g}$ ) by inhalation. ${ }^{9}$ When given intravenously, salbutamol stimulates $\beta_{1}$ receptors of the heart muscle leading to tachycardia and an increase in the systolic blood pressure. The effect on diastolic pressure is usually mild, due to the decrease in peripheral resistance secondary to $\beta_{2}$ receptor mediated arteriolar vasodilation.

The effect of catecholamines at the neuromuscular junction has been studied in animal preparations. Kuba found that adrenaline has two main effects at the neuromuscular junction of the rat diaphragm: a presynaptic stimulatory effect and a postsynaptic inhibitory effect. ${ }^{10}$ The presynaptic effect is mediated via $\alpha$-receptors and is related to an increase in acetylcholine release. The postsynaptic effect is mediated via $\beta_{2}$ receptors, and is related to activation of the membrane $\mathrm{Na}^{+} / \mathrm{K}^{+}$pump, which results in hyperpolarization of the postsynaptic membrane. " This effect can be blocked by specific $\beta$-receptor antagonists as well as by ouabain. ${ }^{12}$ Bowman found that when adrenaline was administered during an infusion of d-tubocurarine, the $\alpha$-stimulatory effect was short and was followed by the more prolonged $\beta$-effect, during which d-tubocurarine induced neuromuscular blockade was potentiated. ${ }^{11}$ It appears that salbutamol has the same neuromuscular effect in humans, except for the $\alpha$ component.

Adrenaline and $\beta_{2}$ sympathomimetic agents have been found to have effects on muscle contractility. In cat soleus muscle, they increase the rate of relaxation, the end result being shortening of the contraction and a slightly reduced twitch height. ${ }^{11,13}$. This effect was probably of negligible importance in our patient. Total disappearance of $T_{1}$ (after the first administration of salbutamol) and of $\mathrm{T}_{4}$ (after the last administration) suggests strongly a neuromuscular blocking effect, because increasing the rate of relaxation cannot explain the total disappearance of any of the trainof-four responses.

Recovery of neuromuscular function after neostigmine appeared to be slower than expected. Neostigmine, 2.5 $\mathrm{mg}\left(33 \mu \mathrm{g} \cdot \mathrm{kg}^{-1}\right)$, given at $45 \% \mathrm{~T}_{1}$ recovery, produced only a $T_{4} / T_{1}$ ratio of 0.6 after ten minutes, in spite of a decreasing alveolar concentration of isoflurane. Using only marginally larger doses of neostigmine (40 $\mu \mathrm{g} \cdot \mathrm{kg}^{-1}$ ), Dernovoi et al. ${ }^{14}$ found a mean $\mathrm{T}_{4} / \mathrm{T}_{1}$ greater than 0.8 , in the presence of more intense blockade $(25 \%$ $\mathrm{T}_{1}$, recovery instead of $45 \%$ ) and greater isoflurane concentrations.

This case report illustrates the effect of acute administration of salbutamol on neuromuscular blockade. To the authors' knowledge, sensitivity of patients on chronic bronchodilator therapy to neuromuscular blocking drugs has not been documented. Such a study might be difficult to perform because most severe asthmatics take many different drugs, all of which may affect the neuromuscular junction. In addition, the neuromuscular effect of $\beta_{2-}$ agonists could be different with prolonged use.

We conclude that acute administration of salbutamol, a $\beta_{2}$ adrenoreceptor agonist, potentiates both pancuronium and vecuronium and is associated with prolonged recovery of the train-of-four after reversal of the residual neuromuscular blockade. This interaction between salbutamol and non-depolarizing muscle relaxants may be clinically important, especially if the $\beta_{2}$-agonist is given shortly before emergence from anaesthesia.

\section{References}

1 Miller RD, Way WL, Dolan WM, Stevens WC, Eger EI. The dependence of pancuronium and d-tubocurarine induced neuromuscular blockades on alveolar concentrations of halothane and forane. Anesthesiology 1972; 37: 573-81.

2 Rupp SM, Miller RD, Gencarelli PJ. Vecuronium-induced neuromuscular blockade during enflurane, isoflurane and halothane anesthesia in humans. Anesthesiology 1984; 60: 102-5.

3 Matsuo S, Rao DBS, Chaudry I, Foldes FF. Interaction of muscle relaxants and local anesthetics at the neuromuscular junction. Anesth Analg 1978; 57: 580-7. 
4 Burkett L, Bikhazi GB, Thomas KC, Rosenthal DA, Wirta $M G$, Foldes FF. Mutual potentiation of the neuromuscular effects of antibiotics and relaxants. Anesth Analg 1979; 58: 107-15.

5 Benz HG, Lunn JN, Foldes FF. "Recurarization" by intraperitoneal antibiotics. BMJ 1961; 2: 241-2.

6 van Poorten JF, Dhasmana KM, Kuypers RSM, Erdmann $W$. Verapamil and reversal of vecuronium neuromuscular blockade. Anesth Analg 1984; 63: 155-7.

7 Stone DJ, Gal TJ. Airway management. In: Miller RD (Ed.). Anesthesia. New York: Churchill Livingstone 1990; 1265-92.

8 Ahrens RC, Smith $G D$. Albuterol: an adrenergic agent for use in the treatment of asthma. Pharmacology, pharmacokinetics and clinical use. Pharmacotherapy 1984; 4: 105-21.

9 Stoelting RK. Pharmacology and Physiology in Anesthetic Practice. Philadelphia, J.B. Lippincott Company 1987; 266.

$10 K u b a K$. Effects of catecholamines on the neuromuscular junction in the rat diaphragm. J Physiol 1970; 211: 551-70.

11 Bowman WC. Pharmacology of neuromuscular function. 2nd Ed. London, Wright. 1990.

12 Clausen T, Flatman $J A$. The effect of catecholamines on $\mathrm{Na}-\mathrm{K}$ transport and membrane potential in rat soleus muscle. J. Physiol 1977; 270: 383-414.

13 Bowman $W C$, Nott $M W$. Actions of some sympathomimetic bronchodilator and beta-adrenoceptor blocking drugs on contractions of the cat soleus muscle. $\mathrm{Br} \mathrm{J}$ Pharmacol 1970; 38: 37-49.

14 Dernovoi B, Agoston S, Barvais L, Baurain M, Lefebvre $R, d$ Hollander $A$. Neostigmine antagonism of vecuronium paralysis during fentanyl, halothane, isoflurane, and enflurane anaesthesia. Anesthesiology 1987; 66: 698-701. 